\title{
Greenhouse gas and energy analysis of substitute natural gas from biomass for space heat
}

\author{
Johanna Pucker ${ }^{\text {a }}$ \\ Robin Zwart ${ }^{\text {b }}$ \\ Gerfried Jungmeier ${ }^{\text {a }}$ \\ a JOANNEUM RESEARCH Forschungsgesellschaft mbH, RESOURCES - Institute for Water, \\ Energy and Sustainability, Steyrergasse 17, $8010 \mathrm{Graz}$, Austria \\ ${ }^{b}$ Energy Research Centre of The Netherlands (ECN), Westerduinweg 3, 1755 LE Petten, The \\ Netherlands
}

Published in Biomass and Bioenergy 38 (2012) 95-101 


\title{
Greenhouse gas and energy analysis of substitute natural gas from biomass for space heat
}

\author{
Johanna Pucker ${ }^{a, *}$, Robin Zwart $^{b}$, Gerfried Jungmeier ${ }^{a}$ \\ a JOANNEUM RESEARCH Forschungsgesellschaft mbH, RESOURCES - Institute for Water, Energy and Sustainability, \\ Steyrergasse 17, 8010 Graz, Austria \\ ${ }^{b}$ Energy Research Centre of The Netherlands (ECN), Westerduinweg 3, 1755 LE Petten, The Netherlands
}

\section{A R T I C L E I N F O}

\section{Article history:}

Received 26 August 2010

Received in revised form

17 February 2011

Accepted 18 February 2011

Available online 30 March 2011

\section{Keywords:}

Substitute natural gas

Bioenergy

Life cycle assessment

Greenhouse gas emissions

Primary energy consumption

Gasification

\begin{abstract}
A B S T R A C T
In this paper, the greenhouse gas and energy balances of the production and use for space heating of substitute natural gas from biomass (bio-SNG) for space heat are analysed. These balances are compared to the use of natural gas and solid biomass as wood chips to provide the same service. The reduction of the greenhouse gas emissions ( $\mathrm{CO}_{2}$-eq.) carbon dioxide, methane and nitrous oxide - and of the fossil primary energy use is investigated in a life cycle assessment (LCA). This assessment was performed for nine systems for bio-SNG; three types of gasification technologies $\left(\mathrm{O}_{2}\right.$-blown entrained flow, $\mathrm{O}_{2}$ blown circulating fluidised bed and air-steam indirect gasification) with three different types of feedstock (forest residues, miscanthus and short rotation forestry). The greenhouse gas analysis shows that forest residues using the air-steam indirect gasification technology result in the lowest greenhouse gas emissions (in $\mathrm{CO}_{2}$-eq. $32 \mathrm{~kg} \mathrm{MWh}^{-1}$ of heat output). This combination results in $80 \%$ reduction of greenhouse gas emissions when compared to natural gas and a $29 \%$ reduction of greenhouse gases if the forest residues were converted to wood chips and combusted. The gasification technologies $\mathrm{O}_{2}$-blown entrained flow and $\mathrm{O}_{2}$-blown circulating fluidised bed gasification have higher greenhouse gas emissions that range between in $\mathrm{CO}_{2}$-eq. 41 to $75 \mathrm{~kg} \mathrm{MWh}^{-1}$ of heat output depending on the feedstock. When comparing feedstocks in the bio-SNG systems, miscanthus had the highest greenhouse gas emissions bio-SNG systems producing in $\mathrm{CO}_{2}$-eq. $57-75 \mathrm{~kg} \mathrm{MWh}^{-1}$ of heat output. Energy analysis shows that the total primary energy use is higher for bio-SNG systems (1.59-2.13 $\mathrm{MWh} \mathrm{MWh}^{-1}$ of heat output) than for the reference systems (in 1.37-1.51 MWh $\mathrm{MWh}^{-1}$ of heat output). However, with bio-SNG the fossil primary energy consumption is reduced compared to natural gas. For example, fossil primary energy use is reduced by $92 \%$ when air-steam indirect gasification technology and forest residues is compared to natural gas. There is no significant difference of the fossil primary energy consumption between the use of solid biomass (0.13-0.15 MWh $\mathrm{MWh}^{-1}$ of heat output) and the bio-SNG systems (0.12-0.18 $\mathrm{MWh} \mathrm{MWh}^{-1}$ of heat output).
\end{abstract}

() 2011 Elsevier Ltd. All rights reserved.

\footnotetext{
* Corresponding author. Tel.: +43 316876 1433; fax: +43 3168761320.

E-mail address: johanna.pucker@joanneum.at (J. Pucker). 


\section{Introduction}

In the EU, energy consumption for heat accounts for $46 \%$ of the final energy use. Heat use is larger than final energy use for transportation (32\% of the EU final energy use) and much larger than the use of electricity ( $18.5 \%$ of the EU final energy use) [1].

Currently biomass for heating is used directly in its solid form as logs, chips or pellets in boilers for heating households and industry and to supply heat for district heating systems. The present use of biomass for heating could be increased by introducing additional supply chains.

Based on data on energy consumption by Eurostat, it can be estimated that about $50 \%$ of heat consumed in the EU is produced from natural gas [1,2]. Production of substitute natural gas from biomass (bio-SNG) is an interesting option to increase the share of heat generation from biomass by exploiting the synergies with natural gas. Conversion of biomass into bio-SNG and subsequent distribution and use can be considered as an additional supply chain for heat from biomass. By distributing energy from biomass in the form of bio-SNG the end user can have a fuel that offers all the advantages of natural gas, such as low emissions, social acceptance, existing infrastructure, wide-spread end use appliance, and the inherent storage and distribution capacity of the natural gas grid to cope with the variable demand. The production of bio-SNG could serve as an alternative gas source, securing the current supply of natural gas and making the EU gas market less dependent from imports.

From the perspective of the biomass chain, there are also advantages: local transportation of solid biomass can be avoided and after the conversion to bio-SNG the distribution losses are minimised. The alternative of heat distribution from solid fuelled combined heat and power installations is restricted to relatively short distances before heat distribution losses become very large.

Bio-SNG can be produced from biomass by anaerobic digestion and upgrading of the produced biogas. In this context it is also called bio methane. Anaerobic digestion is, however, only suitable for a limited number of feedstock that can be digested by the bacteria used in the process. Large-scale thermo chemical production of bio-SNG is suitable for a wider range of biomass feedstock. Thermo chemical production of bio-SNG comprises gasification to convert biomass in a raw
Table 1 - Global warming potentials.

$$
\text { Gas }
$$

$\mathrm{CO}_{2}$-equivalent

$$
\mathrm{CO}_{2}
$$

$\mathrm{N}_{2} \mathrm{O}$

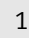

25

298

product gas, gas cleanup and methanation to convert the product gas in bio-SNG.

This paper presents the results of a life cycle assessment (LCA) which was performed to determine the potential of bioSNG to reduce greenhouse gas (GHG) emissions and fossil primary energy use, when used for space heating applications. In this analysis bio-SNG is compared to the use of natural gas and the use of solid biomass as wood chips for space heating applications. The main focus of the analysis is put on the evaluation of large-scale bio-SNG systems and GHG emissions.

\section{Materials and methods}

\subsection{Life cycle assessment}

The calculation of GHG emissions and primary energy use is based on an LCA. The LCA includes all processes, which influence emissions and energy consumption from cradle to grave. It starts with the raw material production (e.g. collection of forest residues, cultivation of energy crops) and ends with the supply of useful energy at the consumer site (e.g. space heat) including all transportation and conversion processes. The life cycle assessment was performed following EN ISO 14040:2006 "Environmental management - life cycle assessment - principles and framework".

Carbon dioxide $\left(\mathrm{CO}_{2}\right)$, methane $\left(\mathrm{CH}_{4}\right)$ and nitrous oxide $\left(\mathrm{N}_{2} \mathrm{O}\right)$ are considered in the LCA. These latter two gases are converted into the equivalent amounts of $\mathrm{CO}_{2}\left(\mathrm{CO}_{2}\right.$-eq.) using global warming potential (GWP) listed in Table 1 [3]. $\mathrm{CO}_{2}$-emissions from biomass are balanced zero, according to IPCC guidelines.

Primary energy use includes all energy inputs which are needed to deliver useful energy, in this case space heat, to the consumer using bio-SNG from biomass, natural gas or directly biomass. The amount of primary energy use is subject to feedstock and technologies used. In this analysis the primary

\begin{tabular}{|c|c|c|c|c|c|c|c|c|c|}
\hline \multirow[t]{3}{*}{ Feedstock } & \multirow[t]{2}{*}{ Yield } & \multirow[t]{2}{*}{$\mathrm{H}_{2} \mathrm{O}$-content } & \multirow[t]{2}{*}{ Fuel consumption } & \multicolumn{4}{|c|}{ Fertilizer use } & \multirow[t]{2}{*}{ Herbicides } & \multirow[t]{2}{*}{ Seeds } \\
\hline & & & & Calcium & Potassium & Nitrogen & Phosphate & & \\
\hline & $\begin{array}{c}\text { [t ha } \\
-1 \\
\mathrm{y}^{-1} \text { ] }\end{array}$ & {$[\%]$} & {$\left[1 \mathrm{ha}^{-1} \mathrm{y}^{-1}\right]$} & $\begin{array}{c}{[\mathrm{kg} \text { ha }} \\
\left.\mathrm{y}^{-1}\right]\end{array}$ & $\begin{array}{c}{\left[\mathrm{kg} \mathrm{ha}^{-1}\right.} \\
\left.\mathrm{y}^{-1}\right]\end{array}$ & $\begin{array}{c}{\left[\mathrm{kg} \mathrm{ha}^{-1}\right.} \\
\left.\mathrm{y}^{-1}\right]\end{array}$ & $\begin{array}{c}{\left[\mathrm{kg} \mathrm{ha}^{-1}\right.} \\
\left.\mathrm{y}^{-1}\right]\end{array}$ & $\begin{array}{c}{\left[\mathrm{kg} \mathrm{ha}^{-1}\right.} \\
\left.\mathrm{y}^{-1}\right]\end{array}$ & $\begin{array}{c}{\left[\mathrm{kg} \mathrm{ha}_{-1}\right.} \\
\left.\mathrm{y}^{-1}\right]\end{array}$ \\
\hline Poplar & 20 & 50 & 136 & 350 & - & - & - & - & 500 \\
\hline Miscanthus & 30 & 50 & 60 & - & 80 & 60 & 10 & 0.8 & 150 \\
\hline Forest residues & $-^{\mathrm{a}}$ & 50 & 9 & - & - & - & - & - & - \\
\hline
\end{tabular}
energy use is divided into:

\section{Table 2 - Basic data of the biomass feedstock used for bio-SNG production.}

a Collection of forest residues. 
Table 3 - Characteristics of bio-SNG systems.

\begin{tabular}{|c|c|c|c|c|c|}
\hline \multirow[t]{3}{*}{ Gasification technology } & Input $^{a}$ & \multicolumn{2}{|c|}{ Output $^{\mathrm{a}}$} & Efficiency $^{c}$ & End use \\
\hline & Biomass & bio-SNG & Power & bio-SNG & Space heat \\
\hline & $\overline{\left[\mathrm{GWh} \mathrm{y}^{-1}\right]}$ & $\overline{\left[\mathrm{GWh} \mathrm{y}^{-1}\right]}$ & $\overline{\left[\mathrm{GWh} \mathrm{y}^{-1}\right]}$ & [\%] & {$\left[\mathrm{GWh} \mathrm{y}^{-1}\right]$} \\
\hline $\mathrm{O}_{2}$-blown entrained flow & 7700 & 4600 & 16 & $60 \%$ & 3900 \\
\hline $\mathrm{O}_{2}$-blown circulating fluidised bed & 7200 & 5400 & $-^{\mathrm{b}}$ & $75 \%$ & 4600 \\
\hline Air/steam-blown indirect & 7200 & 5700 & 32 & $79 \%$ & 4900 \\
\hline
\end{tabular}

a With $8000 \mathrm{~h} \mathrm{y}^{-1}$ full load operation.

$\mathrm{b}$ Additional power form the grid is needed.

c Bio-SNG output divided by biomass input.

- Fossil energy sources: coal, natural gas and crude oil

- Renewable energy sources: biomass, solar energy, water and wind

- Other energy sources: waste (e.g. waste combustion) and nuclear energy

The LCA was performed with the Global Emission Model of Integrated Systems (GEMIS) model, version 4.5 [4].

\subsection{Investigated systems and basic data}

To evaluate the environmental impact of bio-SNG production and usage centralised large-scale bio-SNG systems are compared with:

- Natural gas; and

- The direct use of biomass (which refers to the use of solid biomass as wood chips) for space heat. If bio-SNG is injected into the gas grid it directly replaces natural gas. Therefore the comparison with natural gas is chosen. The direct use of solid biomass represents the current situation of biomass use for space heat.

In total nine different bio-SNG systems are investigated using LCA. The systems are defined by the combination of feedstock and gasification technology.

The different types of feedstock considered in the LCA are:

Forest residues;

Miscanthus; and

- Short rotation forestry (SRF) with poplar.

Table 2 [5] shows the basic data for the biomass feedstock used for bio-SNG production.

The gasification technologies considered in the LCA are:
- $\mathrm{O}_{2}$-blown entrained flow (EF): pressurised entrained flow gasification based on the Siemens pressurised oxygenblown slagging entrained flow gasification technology

- $\mathrm{O}_{2}$-blown circulating fluidised bed (CFB): pressurised oxygen-blown circulating fluidised bed gasification based on the Värnemo demonstration plant; and

- Air/steam-blown indirect: atmospheric indirect gasification based on the Battelle or Silvagas technology.

Table 3 shows the basic data for these gasification technologies. All systems are designed for $1000 \mathrm{MW}$ thermal input capacity of the gasifier. A centralised large-scale system was chosen because bio-SNG has main advantages compared to solid biomass when a significant amount of bio-SNG is injected into the natural gas grid. The efficiencies shown in Table 3 were determined for equipment which will be installed in such a large-scale system.

Before entering the gasification process the biomass is dried to a water content of $15 \%$. For $\mathrm{O}_{2}$-blown EF the dried biomass is further converted into wood powder by torrefaction prior to gasification. Torrefaction is a mild thermal treatment, typically at temperatures in the range of $225-300{ }^{\circ} \mathrm{C}$, in which the biomass losses it's resilient and fibrous properties [6].

As shown in Table 3 power is a by-product of the $\mathrm{O}_{2}$-blown EF and CFB gasification technologies. It is assumed that the power generated as a by-product in the bio-SNG production substitutes power generated in a natural gas fuelled combined cycle power plant. This assumption takes into account that centralised large-scale bio-SNG plants are built in countries with existing natural gas infrastructure where natural gas is a major energy carrier and therefore also used to provide electricity. An increasing amount of bio-SNG in the natural gas grid and therefore also its availability for electricity generation was not included in the investigation.

\section{Table 4 - Basic data for combined cycle power plant and boilers.}

\begin{tabular}{|c|c|c|c|c|c|}
\hline \multirow[t]{3}{*}{ Technology } & \multirow[t]{3}{*}{ Feedstock } & \multirow[t]{3}{*}{ Capacity } & \multirow[t]{3}{*}{ Efficiency } & \multicolumn{2}{|c|}{ Emissions $^{\mathrm{a}}$} \\
\hline & & & & $\mathrm{CH}_{4}$ & $\mathrm{~N}_{2} \mathrm{O}$ \\
\hline & & & & {$\left[\mathrm{g} \mathrm{MWh}^{-1}\right.$ ] } & {$\left[\mathrm{g} \mathrm{MWh}^{-1}\right]$} \\
\hline Combined cycle power plant & Natural gas & 100 MW electric & $53 \%$ electric & 29 & 17 \\
\hline Natural gas and bio-SNG boiler & Natural gas/Bio-SNG & $10 \mathrm{~kW}$ thermal & $85 \%$ thermal & 4.7 & 1.3 \\
\hline Wood chip boiler & Biomass & $10 \mathrm{~kW}$ thermal & $69 \%$ thermal & 52 & 16 \\
\hline
\end{tabular}




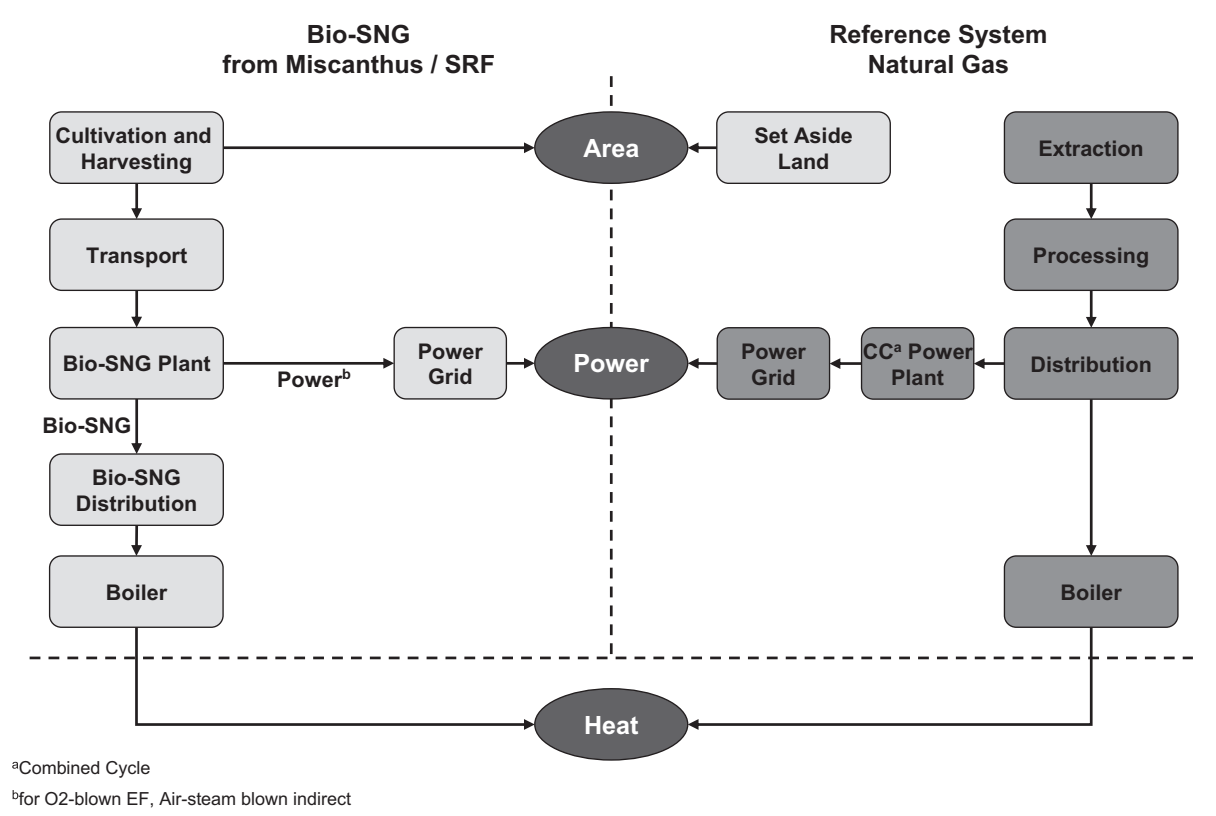

Fig. 1 - LCA comparison for bio-SNG from miscanthus or short rotation forestry and for the reference system with natural gas for space heat.

Space heat is provided with a central heating system using individual boilers. For natural gas and bio-SNG a gas boiler is used. In the case of direct biomass heating with wood from forest residues, SRF or miscanthus a wood chip boiler is chosen. The option of a district heating system was not investigated.

Table 4 [7] shows the basic data for the combined cycle power plant and the two boiler types.

\subsection{Modelling}

The LCA is based on process chains which are designed for each investigated system. A process chain describes the complete life cycle starting with the production of raw materials and ending with the supply of heat for the end user.

Fig. 1 and Fig. 2 show the process chains for selected bioSNG systems compared to the reference systems with natural gas or the direct use of biomass for space heat. The bio-SNG systems provide the same heat amount as the corresponding reference system.

In the LCA it must be considered what happens with feedstock or cultivated area if it is not used to provide feedstock for bio-SNG production - e.g. set aside land instead of cultivation of grassy materials (reference use of agricultural area) or natural oxidation instead of collecting forest residues (reference use of feedstock).

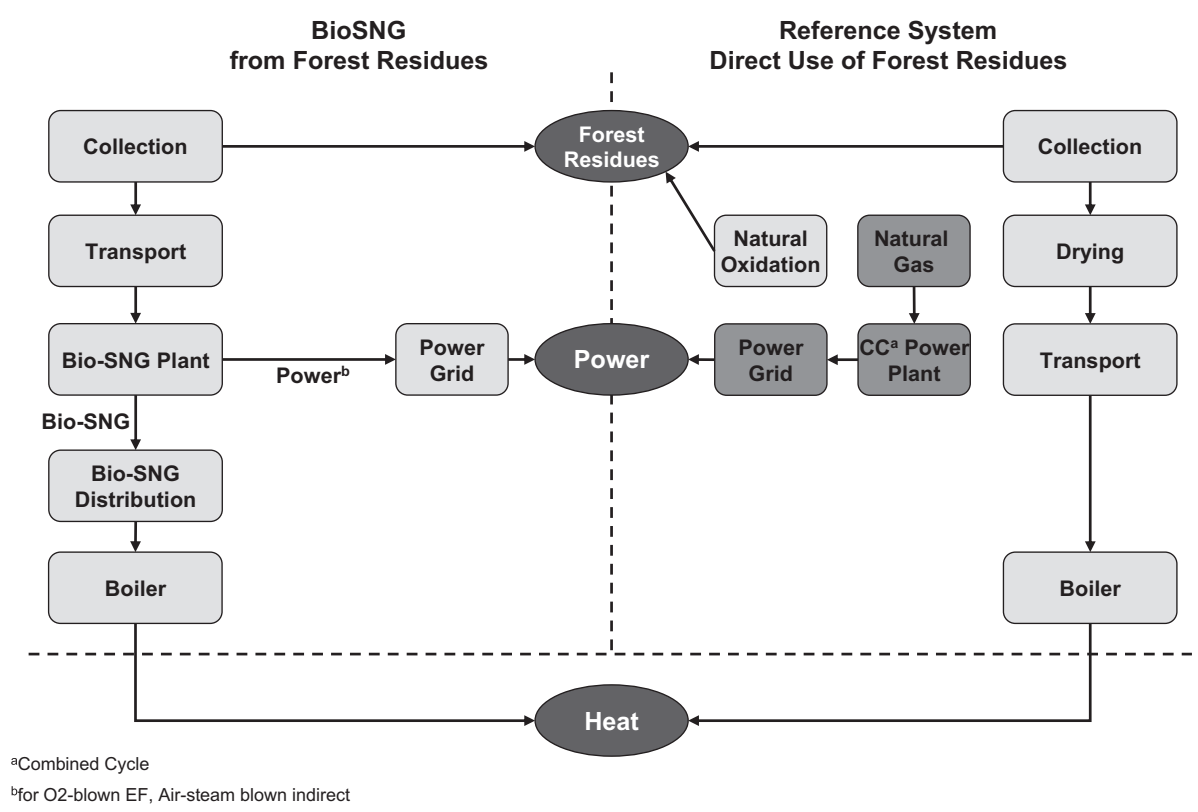

Fig. 2 - LCA comparison for bio-SNG from forest residues and for the reference system with direct use of forest residues for space heat. 


\begin{tabular}{|c|c|c|c|c|c|c|}
\hline \multirow{9}{*}{ 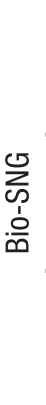 } & \multirow[t]{3}{*}{ Forest residues } & $\mathrm{O}_{2}$-blown EF & 41 & $\mathrm{CO}_{2}$ & $\mathrm{CH}_{4}$ & $\mathrm{~N}_{2} \mathrm{O}$ \\
\hline & & $\mathrm{O}_{2}$-blown CFB & 47 & & & \\
\hline & & Air-steam blown indirect & 32 & & & \\
\hline & \multirow{3}{*}{ Miscanthus } & $\mathrm{O}_{2}$-blown EF & 75 & & & \\
\hline & & $\mathrm{O}_{2}$-blown CFB & 73 & & & \\
\hline & & Air-steam blown indirect & 57 & & & \\
\hline & \multirow[t]{3}{*}{ SRF } & $\mathrm{O}_{2}$-blown EF & 60 & & & \\
\hline & & $\mathrm{O}_{2}$-blown CFB & 62 & & & \\
\hline & & Air-steam blown indirect & 46 & & & \\
\hline \multirow{5}{*}{ 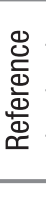 } & Natural gas & Boiler & & & & 288 \\
\hline & Forest residues & Boiler & 45 & & & \\
\hline & Miscanthus & Boiler & 66 & & & \\
\hline & SRF & Boiler & 57 & & & \\
\hline & & $\mathrm{CO}_{2}$-eq in $\mathrm{kg} \mathrm{MWh}^{-1}$ & 100 & 200 & 250 & 300 \\
\hline
\end{tabular}

Fig. 3 - Greenhouse gas emissions for bio-SNG systems and reference systems to supply 1 MWh space heat.

The energy and environmental impacts of by-products are allocated on the basis of substitution. This means by-products of the investigated system replace the production of conventional products and the environmental impact linked to these production processes. Power as by-product at bio-SNG production replaces power generated with a combined cycle power plant using natural gas.

\section{Results and discussion}

Fig. 3 shows the GHG emissions $\mathrm{CO}_{2}, \mathrm{CH}_{4}$ and $\mathrm{N}_{2} \mathrm{O}$ for $1 \mathrm{MWh}$ space heat for all investigated systems. Fig. 4 shows the results for the bio-SNG systems divided into two sections: feedstock supply and bio-SNG production and use. The section "feedstock supply" includes the emissions arising at the process steps "collection" or "cultivation and harvesting" of the feedstock and the emissions from the transport of the feedstock to the bio-SNG plant. The section "bio-SNG production and use" covers the process steps "bio-SNG plant", "pipeline" and "boiler".

Miscanthus is the feedstock with the highest $\mathrm{N}_{2} \mathrm{O}$-emissions. The major parts of these $\mathrm{N}_{2} \mathrm{O}$-emissions originate in agricultural processes when cultivating miscanthus by applying $\mathrm{N}$-fertiliser causing direct $\mathrm{N}_{2} \mathrm{O}$-emissions from soil. The feedstock with the smallest contribution to GHG emissions is forest residues.

The assessment indicates that the most promising gasification technology to achieve a reduction in GHG emissions is air-steam indirect gasification with GHG emissions ranging in $\mathrm{CO}_{2}$-eq. from 32 to $57 \mathrm{~kg} \mathrm{MWh}^{-1}$ of heat output. Because of the high efficiency and the substitution of power generated by a combined heat and power plant using natural gas, the GHG emissions from this technology are slightly lower than the GHG emission from the direct use of biomass for space heat (in $\mathrm{CO}_{2}$-eq. $45-57 \mathrm{~kg} \mathrm{MWh}^{-1}$ of heat output depending on feedstock). $\mathrm{O}_{2}$-blown EF and $\mathrm{O}_{2}$-blown CFB have similar GHG emissions. $\mathrm{O}_{2}$-blown CFB has higher GHG emissions at the bio-SNG production than the other technologies because no power is generated as a by-product. It even needs additional power as auxiliary energy input. As the bio-SNG production is more efficient than for $\mathrm{O}_{2}$-blown $\mathrm{EF}$, the $\mathrm{O}_{2}$-blown $\mathrm{CFB}$ has lower GHG emissions at the collection or cultivation of the feedstock than $\mathrm{O}_{2}$-blown EF.

In comparison to natural gas, the combination of forest residues used in an air-steam indirect gasification result in

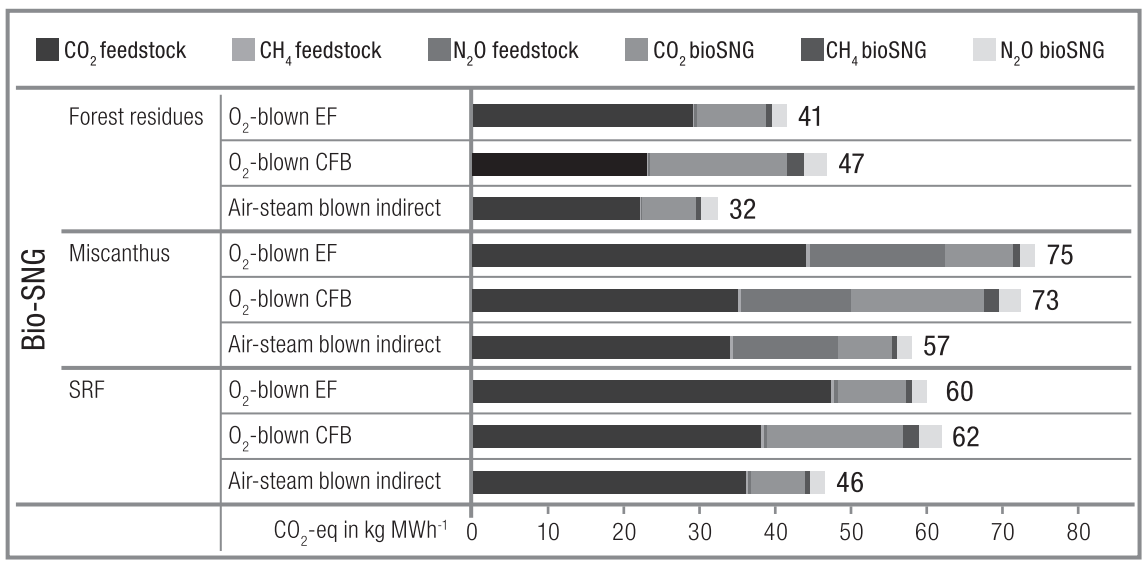

Fig. 4 - Greenhouse gas emissions for bio-SNG systems for 1 MWh space heat shared into emissions from the feedstock supply (feedstock) and emissions from the production and use of the bio-SNG (bio-SNG). 


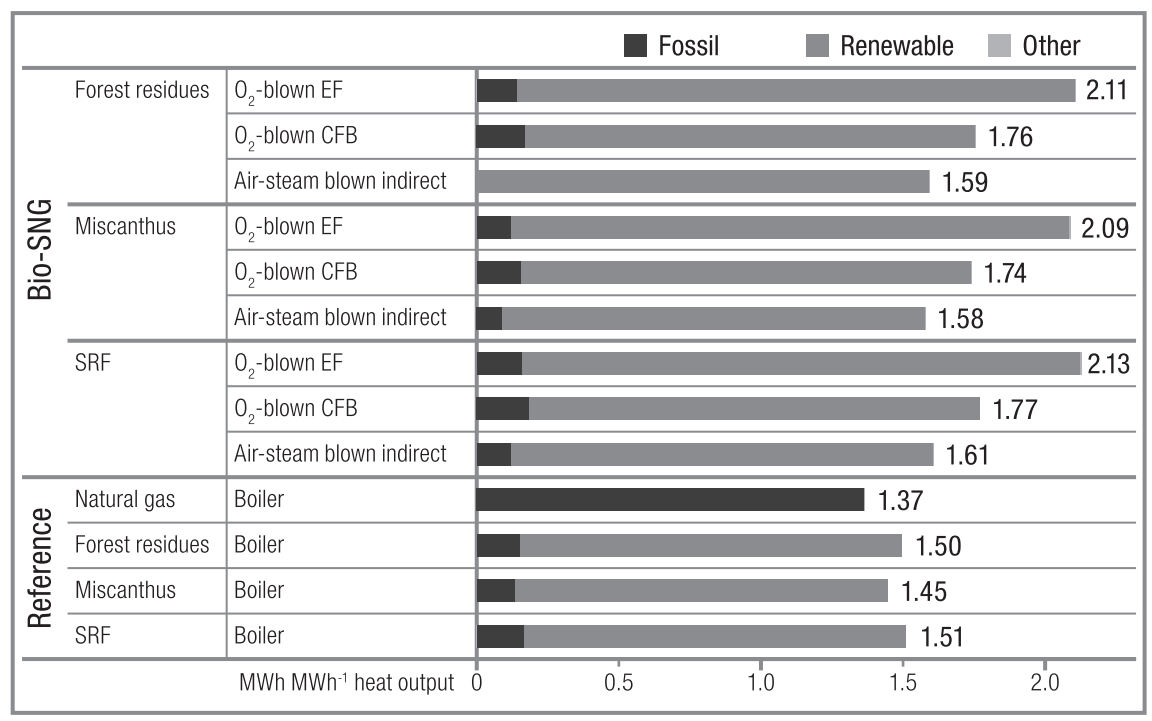

Fig. 5 - Primary energy use for bio-SNG systems and reference systems to supply 1 MWh space heat.

the highest greenhouse gas reduction (89\%). If this combination of feedstock and technology is compared to the direct use of forest residues for space heat, then there is only a $29 \%$ reduction of greenhouse gas emissions.

Fig. 5 shows the primary energy use divided into fossil, renewable and other energy sources for the investigated systems for 1 MWh space heat.

The total primary energy use for bio-SNG systems is

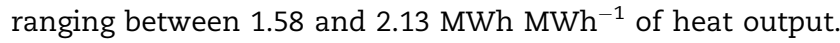
This is higher than for the reference systems with natural gas (1.37 MWh $\mathrm{MWh}^{-1}$ of heat output) or the direct use of biomass. The biomass systems have a total primary energy use of 1.45-1.51 MWh $\mathrm{MWh}^{-1}$ of heat output depending on the feedstock. However with bio-SNG the fossil primary energy consumption is reduced compared to natural gas (Table 5), e.g. with air-steam indirect gasification from forest residues the fossil primary energy use is reduced by $92 \%$ compared to natural gas.
There is no significant difference of the fossil primary energy consumption between the direct use of biomass and the bio-SNG systems. The renewable primary energy demand of bio-SNG systems is $10 \%$ (for air-steam indirect gasification from forest residues) to $50 \%$ (for $\mathrm{O}_{2}$-blown $\mathrm{EF}$ from miscanthus) higher than the direct use of biomass, depending on the feedstock and the gasification technology.

The LCA was performed for centralised large-scale bio-SNG systems where the bio-SNG is injected into the gas grid and used for space heat applications. For the chosen system layout the LCA results show that focussing on GHG emissions and primary energy consumption bio-SNG can be a beneficial alternative to fossil based natural gas. Compared to the direct use of biomass for space heat the results on GHG emissions and primary energy consumption depend on the feedstock and gasification technology used. Other environmental impacts (e.g. particulate emissions), alternative systems layouts (e.g. decentralised bio-SNG systems) or optimisation

Table 5 - Greenhouse gas emissions and fossil primary energy use for bio-SNG systems and reference systems to supply 1 MWh space heat.

\begin{tabular}{|c|c|c|c|c|}
\hline Systems & & & \multirow{2}{*}{$\frac{\text { Greenhouse gas emissions }}{\left[\mathrm{CO}_{2} \text {-eq } \mathrm{kg} \mathrm{MWh}^{-1}\right]}$} & \multirow{2}{*}{$\frac{\text { Fossil primary energy use }}{\left[\mathrm{MWh} \mathrm{MWh}^{-1}\right]}$} \\
\hline & & & & \\
\hline \multirow[t]{9}{*}{ Bio-SNG } & Forest residues & $\mathrm{O}_{2}$-blown EF & 41 & 0.14 \\
\hline & & $\mathrm{O}_{2}$-blown CFB & 47 & 0.17 \\
\hline & & Air/steam-blown indirect & 32 & 0.11 \\
\hline & Miscanthus & $\mathrm{O}_{2}$-blown EF & 75 & 0.12 \\
\hline & & $\mathrm{O}_{2}$-blown CFB & 73 & 0.15 \\
\hline & & Air/steam-blown indirect & 57 & 0.09 \\
\hline & SRF & $\mathrm{O}_{2}$-blown EF & 60 & 0.16 \\
\hline & & $\mathrm{O}_{2}$-blown CFB & 62 & 0.18 \\
\hline & & Air/steam-blown indirect & 46 & 0.12 \\
\hline \multirow[t]{4}{*}{ Reference } & Natural gas & Boiler & 288 & 1.36 \\
\hline & Forest residues & Boiler & 45 & 0.15 \\
\hline & Miscanthus & Boiler & 66 & 0.13 \\
\hline & SRF & Boiler & 57 & 0.16 \\
\hline
\end{tabular}


of the biomass production chain were not part of this assessment and are subject to further investigation.

\section{Acknowledgements}

The work for this paper was performed within the Bioenergy Network of Excellence (NoE) task "Prospects for the production and use of renewable substitute natural gas from biomass" financed by the European Commission.

\section{REFERENCES}

[1] Zwart R, Wilèn C, Pucker J, Plepys A, Peck P, Mäkinen T, et al. Prospects for the production and use of renewable substitute natural gas from biomass. NoE Bioenergy JER 2009-05;2.2:64.

[2] Eurostat. Environment, transport and energy indicators, http:// epp.eurostat.ec.europa.eu/portal/page/portal/product_details/ publication?p_product_code=KS-DK-09-001; 2009 [accessed 15. 02.11]; ISSN-1725-4566; Eurostat Pocketbooks.
[3] Solomon S, Qin D, Manning M, Chen Z, Marquis M, Averyt KB, et al., editors. Climate change 2007: the physical science basis. Contribution of working group I to the fourth assessment report of the intergovernmental panel on climate change. United Kingdom and New York, NY, USA: Cambridge University Press; 2007.

[4] GEMIS standard data set. Darmstadt: Institute for Applied Ecology, http://www.oeko.de/service/gemis/; 2009 [accessed 15.02.11].

[5] Hofbauer H, Schönberger C, Jungmeier G, Canella L, Pucker J, Hausberger S. FT-Treibstoffe aus Biomasse in Österreich - Biomassepotential, Technologien und ökonomische und ökologische Relevanz. Vienna University of Technology, Institute of Chemical Engineering; 2008-12. $176 \mathrm{p}$.

[6] Prins MJ. Thermodynamic analysis of biomass gasification and torrefaction, Ph.D. Thesis, TU/e, Eindhoven, The Netherlands, 2005.

[7] Data set Gemis Austria - Global emission model for Integrated systems Austria version 4.5. Environment Agency Austria, http://www.umweltbundesamt.at/leistungen/ leistung_klima/leistungen_unternehmen_klima/gemis/; 2009 [accessed 15.02.11]. 